NBER WORKING PAPER SERIES

\title{
MARRIED WOMEN'S RETIREMENT BEHAVIOR
}

\author{
Silvana Pozzenbon
}

0livia S. Mitchell

Working Paper No. 2104

\author{
NATIONAL BUREAU OF ECONOMIC RESEARCH \\ 1050 Massachusetts Avenue \\ Cambridge, MA 02138 \\ December 1986
}

\begin{abstract}
Financial support for this research was provided by the Institute for Research on Poverty of the University of Wisconsin, Madison, and Cornell University. We thank Vivian fields for excellent computer programming assistance. Opinions expressed herein are solely those of the authors. The research reported here is part of the NBER's research program in Labor Studies. Any opinions expressed are those of the authors and not those of the National Bureau of Economic Research.
\end{abstract}


NBER Working Paper \#2104

December 1986

Married Women's Retirement Behavior

ABSTRACT

In this paper we examine the economic and family determinants of married women's retirement behavior. A model of wives' retirement decisions is developed and tested empirically using data on working married women. Estimated response parameters are compared to those obtained previously for mals workers. Our findings are directly relevant to policy guestions regarding pension and social Security reform.

Silvana Pozzebon

Department of Labor Economics

NYSSILR

Cornel1 University

Ithaca, NY 14853
Olivia S. Mitchell

Department of Labor Economics NYSSILR

Cornell University

Ithaca, NY 14853 
Though many analysts have studied the factors drawing women into the labor market, less attention has been focused on the process by which women withdraw from market work, particularly at older ages. This paper seeks to fill the gap by examining the economic and family determinants of married women's retirement behavior.

Previous literature on wives' retirement patterns offers little analytical direction. We therefore turn to studies of retirement among male workers to develop our model, recognizirg that men's retirement has been viewed in a relatively simple framework which focuses mainly on economic determinants of retirement outcomes. ${ }^{1}$ In contrast, we postulate that married women's retirement behavior is a more complex phenomenon, affected by both economic and family considerations. Section I. describes our approach to women's retirement decisions within a family context. The empirical analysis uses the Longitudinal Retirement History Survey (LRHS), described in Section II. Estimated response parameters appear in Section III, and are compared to those estimated previousiy for male workers. Our findings are discussed in the context of retirement income policy.

${ }_{1}$ review of the literature on male retirement patterns appears in Mitchell and Fields (1982). Several newer studies include Bazzoli (2983), Fields and Mitchell (1984 a,b), Gustman and Steinmeier (1986), Hanoch and Honig (1983) and Honig and Hanoch (1985). Related models have also been used to examine unmarried women's retirement, and conclude that factors determining retirement among these women are similar to those affecting males. See hanoch and Honig (1983) and Honig (1985), as well as Schwab and Irelan (1981). 


\section{Medeling Wives' Retirement Patterns}

Previous research on married women's retirement behavior consists mainly of cross-sectional empirical analyses, initiated by Bowen and Finegan's classic labor supply study (1969). Most relevant to the present study is a multivariate labor force participation model estimated using 1960 Census data on wives aged 55-64, and 65-74. Two significant findings emerge Erom that analysis: older wives appear to work less when their. spouses are retired, and when family income is greater.

Subsequent research on older wives' labor force withdrawal appears in studies by henretta and O'Rand (1980, 1983), who examine several different waves of the IRHS to establish the prevalence of retirement patterns among women. 2 Most important for our purposes are the authors' findings that wives' retirement is powerfully influenced by both econemic variables (e.g. wages and pension eligibility), and noneconemic variables (e.g. having a husband in poor health, having dependent children). The importance of both economic and noneconomic factors in wives' retirement decisions is further supported by the empirical research of Clark and Johnson (1980) and Clark et al. (1980). Here, cross-sectional labor force participation equations indicate that married females are more (less) likely

\footnotetext{
These authors merge and compare information from a number of different LRHS waves, so their dependent variabies have lifecycle aspects. Howevex they do not consider the complex income opportunities potentially available to women at different retirement ages, and women's responses to them, which are the focus of the present paper.
} 
to work when own wages (retirement benefits) are high, and when the husband is working.

Prior studies thus suggest that both family and economic variables affect older wives' labor market attachment. However, research to date does not cast women's behavior into a life cycle framework: 3 This is a serious drawback, insofar as retirement decisions are by their nature dependent on current as well as future income and leisure opportunities. 4 The

- intertemporal structure of retirement income opportunities and hence the retirement decision is not explicitly recognized in studies taking a cross-sectional perspective.

To develop a model of wives' retirement decisions in a life cycle context, we assume that, at the planning date (time 0 ), the wife selects an optimal retirement date $R^{*} . R^{*}$ is interpreted as the point at which the woman withdraws from the labor force. The planning date is defined to be the year in

The exception to this generalization appears in a theoretical effort by Clark and Johnson (1980), and Clark et. al. (1980). They use numerical analysis to deduce labor market patterns of older workers given a complex two-person, family lifetime utility model which also includes home production and human capital investments. This framework is so general as to be intractable for the purposes of statistical analysis, however, and has not been pursued in subsequent work. In fact, the empirical analysis in those studies is essentially crosssectional, as described above, reflecting this difficulty.

${ }^{4} \mathrm{~A}$ survey of life cycle retirement models appears in Mitchell and Fields (1982). 
which her husband turns age 60.5 we further postulate that she - seeks to maximize her remaining lifetime utility, 6 a function of two arguments: remaining years to be spent in retirement (RET), and the present discounted value of income streams (PVY). $U=f[\operatorname{PVY}(R), \operatorname{RET}(R)]$.

RET is equal to $D-R$, where $D$ is the expected date of death, and $\mathrm{R}$ is the woman's retirement date. In previous research on male retirement, it has been assumed that RET is equivalent to years spent in leisure. However, for married women, it is quite likely that a significant portion of the nonlabor market period may be devoted to home production activities. While this recognition need not alter the formulation of the utility function, it carries the implication that women's valuation of RET years may be higher than men's. PVY(R) is the discounted sum of three income components: earnings flows [PVE(R)], pension benefit streams [PVP(R)], and Social Security streams [FVS(R)]. All three streams can (and 5 In previous research, we assume that the husband's retirement planning date coincided with age 60 (Fields and Mitchell, $1984 \mathrm{~b})$. Since the empirical work below is based on a subset of the same sample of individuals (and their wives), this assumption is computationally convenient and we believe has little impact on estimated outcomes in cases where husbands and wives are close in age. We subject the assumption to sensitivity analysis by focusing on cases where the age difference across spouses is significant.

${ }^{6}$ It will be assumed that the utility function is monotonic, twice differentiable, concave, and stable over time. The budget. constraint is also postulated to be stable over time, though in the empirical analysis, this assumption is relaxed, as is the assumption of a fixed $D$. The latter is replaced with declining survival probabilities derived from life tables current at the time the women (and their spouses) were making retirement decisions. 
generally do) depend on when the woman retires, since earnings at older ages need not be constant, and pension as well as Social Security benefit rules are not generally actuarially neutral. The present value of earnings at a specific retirement date, $R$, is expressed as follows:

$$
\operatorname{PVE}(R)=\int_{0}^{R} E_{t} g_{t} d t,
$$

where $E_{t}$ is the wife's earnings net of income taxes and required pension/social security contributions, accruing from the planning date (time 0 ) to the retirement date. A discount factor, $g_{t}$, captures time preferences and mortality. The expression PVP(R), in turn, is specified as:

$$
\text { . } \operatorname{PVP}(R)=\int_{R}^{D} P_{t}(R) g_{t} d t .
$$

This represents the discounted sum of the wife's employerprovided pension benefits, given that she retires at age $R$, and she is eligible for a pension. A similar expression indicates the discounted value of social security benefits:

$$
\operatorname{PVS}(R)=\int_{R}^{D} s_{t}(R) g_{t} d t \text {. }
$$

In addition to the woman's own earnings and retirement benefits, the discounted total value of her husband's income is also allowed to affect her retirement decision. In this paper, the wife is assumed to make her retirement decision subsequent to her husband, taking as given his retirement age choice. We recognize that this formulation is not a fully simultaneous one; rather, it is the life-cycle equivalent to what kilingsworth 
(1983) describes as a "male chauvinist" model in the static oneperiod framework. The justification for such an assumption stems from the empirically intractible nature of a fully simultaneous model at this juncture. This arises from the essential nonlinearity of the income opportunity constraints in our data set, wherein a wife's retirement benefits depend on when her husband retires. 7 In addition, casting the wife's retirement decision as conditional on the husband's seems plausible for the generation of women retiring in the 1970's, which is the group we will examine empirically below.

In general, the wife's consumption (C) from time 0 onward, must not exceed the present value of her total income $(P V Y(R))$, plus the value of nonlabor income including her husband's contribution (w):

$$
C=P V Y(R)+W .
$$

Subject to this income constraint, and the total time constraint $(R E T=D-R)$, the wife is assumed to select her optimal retirement date $R^{*}$ such that she maximizes her utility. This is accomplished by equating the marginal utility of an extra

\footnotetext{
Tunder the U.S. Social Security system, a wife is entitled to receive either one-half of her husband's benerits, or benefits based on her own work history, whichever is greater. A wife may also retire prior to her spouse on the basis of her own work eligibility, and then obtain a berefit increase when her husband retires later (if benefits based on her work history are smaller). These instituticnal realitics imply that conditional and very complex budget sets would have to be developed for each of the two workers, for every possible retirement age.

Estimating such a model is not currently possible. In the interest of reducing the dimensionality of the problem, the "wife as follower" construct described above, thus seems particularly appropriate for the cohort of interest here.
} 
retirement year with the marginal utility of consumption from working one more year. ${ }^{8}$ An interior solution is obtained if equality between the two conditions is achieved between the planning date (time 0 ) and the worker's date of death (D); otherwise the worker never retires (if the marginal utility of consumption always exceeds the marginal utility of an extra year of leisure), or retires immediately (when the reverse is true). Previous research has shown that it is virtually impossible - to obtain clearcut comparative static predictions regarding the effect of exogenous variables on $R^{*}$, the optimal retirement date. This ambiguity arises from the nonlinearities inherent in older workers' income opportunity sets. 9 Earlier research by Fields and Mitchell (1984b), however, offers some direction in this instance. The following appear to hold true empirically for male workers around the retirement date:

1. An increase in the worker's nonlabor income, or the pension income available for retirement at age 60 (holding constant subsequent accrual rates) induces earlier retirement, via a negative income effect on labor supplied.

2. An increase in earnings, or the pension/Social security accrual rate, raises income as well as the price of leaving the

${ }^{B_{T}}$ The Lagrangian for this constrained maximization problem yields first order conditions $\partial \mathrm{U} / \partial \mathrm{RET}=\partial \mathrm{U} / \partial \mathrm{C} * \partial \mathrm{PVY} / \partial \mathrm{R}$, where $\partial \mathrm{PVY} / \partial \mathrm{R}=$ $E_{R} g_{R}-P_{R} g_{R}+\partial\left[\int^{D}\left(P_{t}{ }^{\star} g_{t}\right) \partial t / \partial R\right]$

$R+1$

9Burbidge and Robb (2980), MacDonald and Carliner (1982), Fields and Mitchell (1984b) point out some of the ambiguities inherent in this type of model. 
labor force. Hence this type of change has both an income effect (inducing earlier retirement), and a substitution effect (inducing delayed retirement). For males, the substitution effect appears to dominate, so that increasing the rewards for deferring retirement produces later retirement ages. It is expected that similar predictions about the roles of economic variables can be made for working wives.

In addition to these economic variables, we also wish to examine the role of family factors in wives' retirement. For instance, the studies cited earlier suggest that married women respond to their husband's health and retirement status, the presence of dependent children, and the age difference between the two spouses. Unfortunately, theory provides few clearcut predictions about the expected signs on these variables. For example, a husband's poor health or the presence of dependents generates more financial need, so the wife may remain employed longer. On the other hand, such family factors may be conducive to earlier retirement if they raise the value of the woman's nonmarket time. Only empirical analysis can clarify further the actual direction of these effects.

\section{Data and Variables}

The sample of older women examined in this paper consists of the wives of white married men surveyed by the social Security Administration over the ten-year period between 1969 and 1979. Husbands in these couples are examined by Fields and Mitchell (1984b). The wives' sample includes women working in 1969, whose husbands also work in that year. In addition, the 
women and their husbands are present in all waves of the LRHS between 1969 and 1979. Only private sector wage and salary workers are included in the analysis, since no pension data are avairable for government or military employees. The sample is further restricted to wives aged 54 to 62 in 1969 (husbands of these women were age 59-61 in that year).10 the resulting sample size is 139 working women in 1969, whorn we follow for ten years.

\section{A. Retirement Ratterns of Married women}

The dependent variable analyzed here is RETAGE, or the age when each wife first describes herself as without a job and not looking for employment. Table 1 summarizes key characteristics of women's retirement patterns using this definition.11 The average retirement age is 62 , which is somewhat younger than the male average of 64 . About 42 of the group retires prior to age 62 (termed here "very early" retirement), 35\% retire at or after

10 On the one hand, the lower-bound age restriction follows from our reluctance to project needed income figures for all possible retirement dates, for very young sample members. On the other hand, the age restriction for older women reduces the possibility of sample selection bias, since some of the older women would have retired by the first survey date (in 1969).

11In a few cases, the wife first intereviewed in 1969 was still in the labor force in 1979, when the LRHS interviews ceased. In such cases, RETAGE is set equal to the women's expected age of retirement. In additional analysis, we also explore other retirement age definitions including the age at which workers leave their 1969 jobs, and the age at which they accept social Security benefits. The results using the former definition are guite similar to those reported below, so we do not describe them in detail here. Defining retirement as the age of Social Security acceptance proves relatively uninteresting for marriedi women, since a majority of the sample of wives appears to retire (using other definitions) before age 62 , the age of first eligibility for social security. 
TABLE 1

RETIREMENT AGE PATTERNS OF MARRIED WOMEN IN THE LRHS SAMPLE

A. Continuous Retirement Variablo

\begin{tabular}{|c|c|c|}
\hline VARIABLE & $\begin{array}{c}\text { MEAN } \\
\text { ISTD. DEV.I }\end{array}$ & VARIABLE DEFINITION \\
\hline \multirow[t]{2}{*}{ RETAGE } & $\begin{array}{l}62.0 \\
{[4.2]}\end{array}$ & $\begin{array}{l}\text { Wife's retirement age, defined as the age } \\
\text { when the rife first describes herself as } \\
\text { working or looling for work, given that } \\
\text { she vorked in } 1969 \text {. If the ife is still } \\
\text { employed in } 1979 \text {. RETAGE is set equal to } \\
\text { her expeoted age of retirement. }\end{array}$ \\
\hline & \multicolumn{2}{|c|}{ B. Discrete Retirement Variablo } \\
\hline VARIABLE & FREOUEFICY & VARIABLE, DEFINITION \\
\hline $\begin{array}{l}\text { Very Early } \\
(\text { CHOICE }=1) \\
\text { - }\end{array}$ & $42 \%$ & RETAGE $<62$ \\
\hline$\stackrel{\text { Early }}{(\mathrm{CHOTCE}=2)}$ & $35 \%$ & $62 \leqslant$ RETATE < 65 \\
\hline$\stackrel{\text { Normal }}{(C H O I C E}=3)$ & $14 \%$ & $65 \leqslant$ RETAGE < 67 \\
\hline $\begin{array}{c}\text { Late } \\
(\mathrm{CHOICE}=4)\end{array}$ & $10 \%$ & RETAGE 267 \\
\hline & & ' \\
\hline
\end{tabular}

Source: Authors' calculations from IRHS wives described in text. 
age 62 but before age 65 ("early" retirement), 14 \& retire at or after age 65 but before age 67 ("normal" retirement), and 10 : retire at of after age 67 ("late" retirement). Table 2 summarizes the correspondence between wives' retirement patterns and those of their husbands. Overall, two-thixds of the women in this cohort retire prior to or at the same time as their husbands. Interestingly, this pattern seems invariant to whether the wives are younger or older than their spouses.

\section{B. Explanatory Variables}

Three types of explanatory factors are used to explain working wives' retirement patterns: measures of income opportunities, measures of RET or years away from the labor force, and family responsibility measures. These are discussed in turn, below. Specific definitions as well as descriptive statistics appear in Table 3 .

1. Income opportunities

Discounted income streams available to each wife are computed for four possible retirement ages (RETAGE $=60,62,65$ and 67). These income streams are defined as PVY(RETAGE) + HPVYR, 12 and consist of present values of the wife's income opportunities that she could receive if she were to select one of the four alternative retirement dates, plus her husband's income given his retirement date. 13

12This sum is the empirical equivalent of PVY $(R)+W$ in the general model discussed above.

${ }^{13}$ Fields and Mitchell (1984b) describe the construction of HPVY: in some detail for LRHS males in this sample. 
TABLE 2

WIVES' RETIREKENT PATTERNS RELATIVE TO HUSBANDS'

\begin{tabular}{|c|c|c|c|}
\hline RETIREMENT PATTERN & $\begin{array}{c}\text { ROW TOTAL } \\
(\%)\end{array}$ & $\begin{array}{c}\text { WIFE'S AGE < } \\
\text { HUSBAND'S AGE } \\
\text { (\%) }\end{array}$ & $\begin{array}{c}\text { WIFE'S AGE 2 } \\
\text { HUSBAND'S AGE } \\
(\%)\end{array}$ \\
\hline $\begin{array}{c}\text { WIFE RETIRES PRIOR } \\
\text { TO HUSBAND }\end{array}$ & 54 & 42 & 12 \\
\hline $\begin{array}{l}\text { PIFE RETIRES WITH } \\
\text { HUSBAND }\end{array}$ & 14 & 9 & 5 \\
\hline $\begin{array}{l}\text { WIFE RETIRES AFTER } \\
\text { HUSBAND }\end{array}$ & 32 & 24 & 8 \\
\hline COLUMN TOTAL (\&) & 100 & 75 & 25 \\
\hline
\end{tabular}

Scurce: Authors' calculations from the LRHS sample of wives described in the text. 
TABLE 3

EXPLANATORY VARIABIES: DEFINITIONS AND DESCRIPTIVE STATISTICS a,

\begin{tabular}{lll}
\hline & SIANDARD & \\
VARIABLE MEAN DEVIATION & VARIABLE DEFINITION \\
\hline
\end{tabular}

A. Income

PYY60 $17.68 \quad 15.83$ Preeent value of the ife' $^{3}$ real expected

PYY62 $28.93 \quad 17.86$ income then her retiresent age equals 60 ,

PVY65 $41.9320 .1462,65$, or 67 , assuming the husband's

PVY67 46.9820 .87 retirement ago is known. Income is

discounted to 1970 .

YCHANGE $24.25 \quad 15.23$ Present discounted value of rife's

expected real income at 65 (PVY65) minus

present discounted value of wife's

expected real income at 60 (PVY60).

HPYYR $51.78 \quad 18.47$ Present discounted value of the husband's real expected income assuming his actual retirement age is his planned retirement age. Inoome is discounted to 1970.

Retirement age for males is defined as the age when a male worker leaves his 1969 job.

B. RET :

RET60 20.07 0.55. Years the wife spends in retirement when RET62 $18.07 \quad 0.55$ retirement age equals $60,62,65$, or 67 . RET65 $15.07 \quad 0.55$ RET is the differenoe botween the rife's RET67 $13.07 \quad 0.55 \quad$ lifo expectancy (in 1969) and retirement age. RET varies by cohort. 
TABLE 3 (CONTVNUED)

EXPLANATORY VARIABLES: DEFINITIONS AND DESCRIFTIVE STAPISTICS

\begin{tabular}{ll}
\hline & STAIDARO \\
VARIABLE MEAN DEYIATION & VARTABLE DEFJNITION \\
\hline
\end{tabular}

\section{c. Family}

AGEDIFF 2.892 .30 Husband's age minus wife's age.

DEPCH $\quad 0.22 \quad 0.42=1$ if the household supports children in 1969 .

$=0$ else

HHPOOR $0.05 \quad 0.23=1$ if a health index rates the husband as having poor health in any survey year prior to his retirement.

$=0$ olse

$\begin{array}{llll}\text { HRET60 } & 0.44 & 0.50 & =1 \text { if the husband is retired when the } \\ \text { HRET62 } & 0.65 & 0.48 & \text { wife's retirement age equals } 60,62, \\ \text { HRET65 } & 0.90 & 0.30 & 65, \text { or } 67 . \\ \text { HRET67 } & 0.98 & 0.15 & =0 \text { else }\end{array}$

Notes:

a. Income values are in thousands of 1970 dollars.

b. Sample size is 139 for all varjables except HHPOOR where $N=129$, and DEPCH where $\mathrm{N}=124$. 
Computing the income amounts relevant to these four retirement dates requires a number of separate calculations for discounted values of earning streams (net of taxes), Social Security streams, and pension streams.14 The wife is assumed to be looking forward from the planning date, when her husband is age 60 (in about 1970, for the men in our sample). Gross earnings are projected for each individual, using previous actual earnings.15 After converting these to 1970 dollars, income and payroll taxes are subtracted based on the rules in effect at the planning date. Social security benefit computations for the wife are based either on her own record, or half of her husband's, whichever is larger.16 These calculations incorporate information about the husband's retirement status at each point in time, and use the rules in place at the planning date. If a wife is eligible to receive a pension, the PVY equation also includes her (real) pension benefit stream. Because the LRHS provides very incomplete data on women's pensions, expected benefits for eligible women are derived from modifications of industry-level data on male retirees' benefits presented in Kotlikoff and Smith (1983). These figures are given for age-65 retirees, and are adjusted for earlier and ${ }^{14} \mathrm{~A}$ data appendix describing the construction of these variables will be made available on request.

${ }^{15}$ This method is used in Bazzoli (1983) and Fields and Mitchell (1984b) .

16 Similar benefit rules apply to husbands, but because husbands' benefits are generally larger than half their wives' due to women's intermittent workforce attachment, this possibility is set aside in the empirical computations. 
later retirement using an approach described by Fields and Mitchell (1984b). Finally, women's benefit levels are adjusted downward by a factor of $22 \%$, based on evidence reported by Lazear and Rosen (1984) who study sex differentials in pension benefit amounts. Note that the analysis assumes that Social Security benefits are expected to be constant in real terms, but that pensions will fall at the inflation rate.

Table 4 summarizes alternative values of PVY, or the discounted values of income streams from the viewpoint of the planning date, expressed in 1970 dollars. Each year's income amounts are discounted by a 2 s. real interest rate, and the probability of mortality which varies by cohort. 17 It is evident that all income components rise with the woman's retirement age until age 65 , on average, and only pensions decline thereafter. In addition, income opportunities for working wives are roughly $50 \%$ of men's at all retirement ages.18 The budget set is also highly nonlinear, insofar as the returns to another year of work vary depending on the worker's age. This finding is similar to that discerned for male LRHS workers by Fields and Mitchell (1984b).

The final component of the older woman's budget set is described as HPVYR, or the present value of the husband's expected income stream as of the planning date, taking his

17The sample of wives encompasses nine birth-year groups, since it includes women age 54-62 in 1969. Age-specific mortality rates are incorporated accordingly.

18Fields and Mitchell (1984b), p. 42. 
TABLE 4

MARRIED WOMEN'S RETIREMENT' BUDGET SETS:

AVERAGE PRESENT DISCOUNTED VALUES AT SELECT RETIREMENT DATES $(1970 \$)$

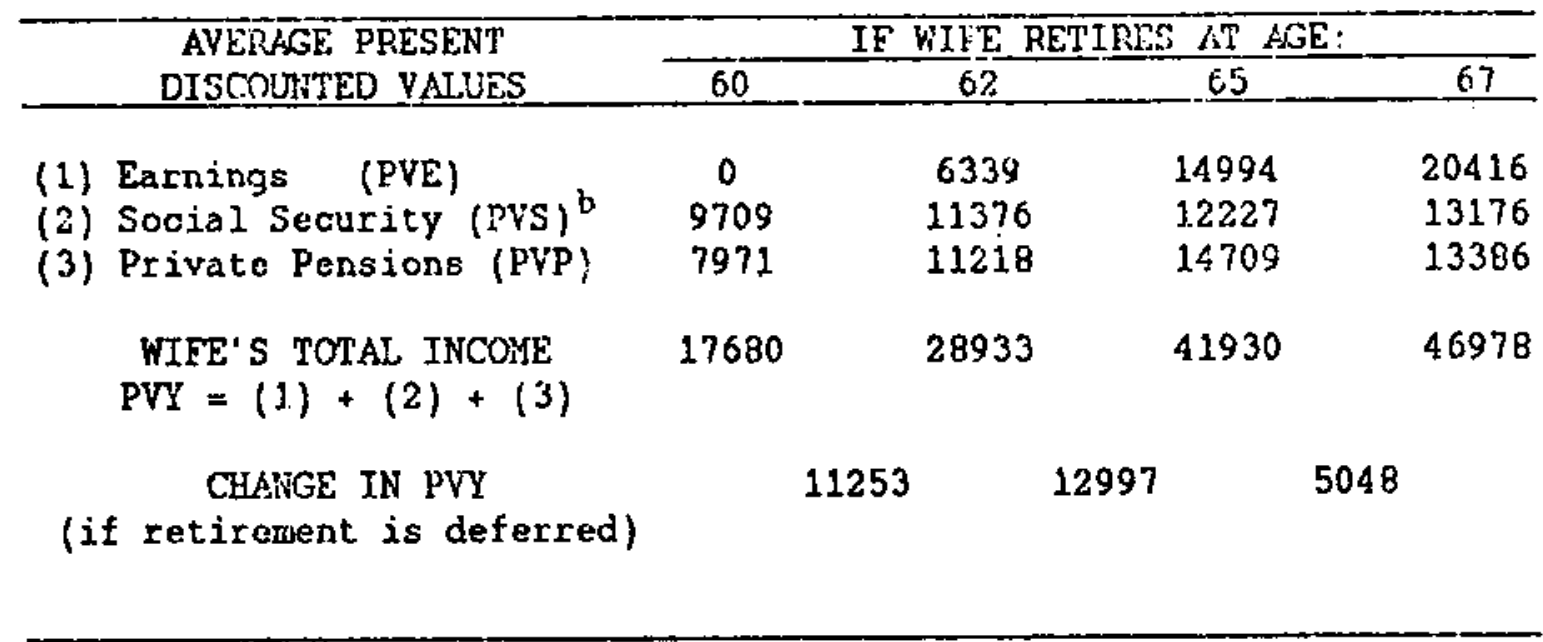

Notes:

a. All olements of the budget set are discounted to 1970. At this point, the spouses of the vives in the sample are approximately 60 years of age.

b. Social Security computations posit that wives retire at the stated age and apply for benefits vhen first eligible. Wives are also assumed to know their husband's retirement age. 
actual retirement date as his optimal retirement point. I9 This averages around $\$ 52,000$ in 1970 dollars, in contrast to an average woman's PVY of $\$ 18,000$ if she were to retire very early (i.e. at age 60 ) and $\$ 47,000$ if she were to defer retirement to age 67 , a "late" retirement date.

\section{Years out of the Iabor Eorce}

The model above posits that women value years out of the labor force, in addition to income. In practice, the retirement. - period, or RET, is measured as the difference between a wife's life expectancy and her retirement age. Hence it varies by age in 1969, as well as across retirement dates for each woman.

\section{Family Responsibilities}

Several formulations of family responsibility variables äe feasible with IRHS data. We consider the following: DEPCH, indicating the presence of dependent children in 1969; HRET, indicating whether the husband is retired; and HHPOOR, indicating whether the husband is in poor health in any survey year prior to his retirement. 20 We also develop a variable measuring the difference between the husband's and the wife's age (AGEDIFF), on the hypothesis that younger women married to older men may exhibit a different labor force attachment than do women closer in age to their spouses.

TMale mortality probabilities are taken into account, along with a 2 s real discount rate.

20 Other family variables were also investigated, including the presence of dependent siblings or parents, but missing data and small resultant sampie sizes limit the strength of these findings. The health variable is described in greater detail by Bazzoli (1983). 


\section{Empirical Fermulations and Findings}

Two empirical formulations are developed below, along the lines suggested by Fields and Mitchell (1984b): a regression framework, and a discrete choice logistic model. Each is discussed in turn.

\section{A. The Regression Framework}

One empirical formulation of the model described earlier postulates a linear relationship between base income, and the - rewards for postponing retirement. Base income is defined as the expected present value of income the wife would receive if she retired very early, taken here to be age 60 (PVY60). Assuming that retirement years are a normal good, the ordinary income effect of higher base income should induce earlier retirement. In addition, diminishing marginal utility of income may also imply that wealthier couples will retire earlier.

The rewards for deferring retirement are summarized in a variable we call YCHANGE, or the increase in the wife's discounted income stream if she defers retirement to age 65 , versus retiring at 60 . Higher values of yCHANGE imply a negative income effect, but a positive substitution effect, as noted above. Which effect dominates for married women has not yet been empirically established.

Empirical estimates of the effects of these economic variables appear in Table 5, as well as estimates of the factors reflecting family considerations. Column 1 shows the simplest model, consistent with that estimated for males by Fields and Mitchell (1984b). The sign of the own income variable is 
negative, in accord with expectations and earlier research. However, the coefficient is not statistically significant at conventional levels. The estimated YCHANGE coefficient suggests that the substitution effect dominates the income effect among females, as has been found for males, but the net result is not statistically significant.

As the results in columns $2-4$ indicate, higher values of HPVYR are associated with later rather than earlier retirement among wives which is contrary to the model's predictions. 21 The effect is not overwhelmingly strong, but does suggest marital selection bias; that is, a woman married to a "workaholic" may share her husband's tendency to delay retirement.

The influence of variables indicating family responsibilities appears to be quite substantial, in the sense that the new variables are often significant and considerably increase explained variance. The significant effect of AGEDIFE in column 3, indicates that women retire earlier when their husbands are much older then they. This seems to suggest that husbands' health problems are more severe in these relationships, but the effect persists when a proxy for health is introduced (HHPOOR). Indeed, a spouse's poor health is associated with delayed rather than earlier retirement among working women in our sample, perhaps because of greater need for employer-provided health insurance coverage. The strong negative effect of AGEDIFF is probably best attributed to working women's

21 This finding also contradicts cross-sectional findings for similar variables; for instance, see Bowen and Finegan (1969). 
desire to share the retirement period with their spouses, indicating some degree of complimentarity in leisure time of two-earner couples. Finally, the retirement outcomes of wivcs in households with dependent children are not discernably different from those without such dependents.

In overview, the evidence from the regression model suggests that a working wife's retirement decision is only weakly affected by her life cycle income opportunities. Neither income nor substitution effects prove statistically different from zero. Factors playing a more powerful role are variables indicating her husband's income and health, as well as the difference between the spouses' ages. One variable which apparently plays no significant role is the presence of dependent children.

\section{B. Iogit Models}

Married women's retirement behavior may also be set in a discrete choice framework, which characterizes the retirement decision as a utility maximizing selection among several alternatives. This model is more general than the regression approach, since income and leisure information relevant to each retirement date can be explicitly incorporated. This structure also allows nonlinearities in the budget set to be represented more directly.

The basic formulation supposes that individual $i$ selects alternative $j$ based on its attributes, defined in the present 
setting to be the RET and income associated with retirement clate j:

$$
U_{i j}=\left[\left(P V Y_{i j}\right)^{B} *\left(R^{B} T_{i j}\right)^{\infty}\right] * c_{i j}
$$

with $B$ and $\sigma$ are assumed constant for all $i$ and $j$. Taking logs and making appropriate assumptions about the error term $\left(e_{i j}\right)$ yields the following expression for the probability that an individual will select retirement age $j$ :

$$
\mathrm{P}_{j}=\exp \left(\mathrm{V}_{\mathrm{j}}\right) /\left[\Sigma_{\mathrm{K}} \exp \left(\mathrm{V}_{\mathrm{k}}\right)\right]_{\text {, }}
$$

where $V_{j}=\left[\beta \star \ln \left(\mathrm{PVY}_{i j}\right)+\varnothing \star \ln \left(\mathrm{RET}_{i j}\right)\right]$, and $\mathrm{k}(=1, \ldots, \mathrm{K})$ indicates the range of possible choices.

McFadden (1981) has pointed out that this conditional Logit model has the virtue of being derived from utility theory. However, the model has been criticized by others, in that it assumes behavior is unaffected by the presence or absence of alternatives not chosen by the individual; this is the the IIA assumption, or independence of irrelevant alternatives. Below we test whether IIA is a suitable assumption in the context of married women's retirement decision.

Table 6 reports four sets of estimated Logit coefficients. The simplest formulation appears in Column 1 , in which only the wife's income and RET are assumed to enter her utility function. Here we see that the effect of own income opportunities on wives' retirement ages is far smaller than for married men; indeed the effect of LNPVY is not significantly different from zero. The effect of LNRET is positive and significant. One way to assess the findings is to compute the relative weight associated with own income, versus leisure. The ratio of these 
two coefficients for married women is .03 in this sample, a value considerably smaller than the .60 obtained for LRHS males in previous work (Fields and Mitchell, 1984b). In general, then, married women's income opportunities do not seem to powerfully influence their retirement patterns, though the utility weight attached to non-work years is large and statistically significant. This pattern is compatible with the view that women's valuation of RET years may be higher than men's because of home production activities.

Columns 2-4 extend the conditional Logit formulation of the first column, by incorporating family responsibility variables. These do not vary across retirement states for a given person; instead, choice-specific estimates of coefficients are produced. vespite the fact that the "mixed" Logit models include more variables, essentially the same conclusions hold for the wife's own income and RET effects. There is, however, a stronger effect of husband's income: women are significantly less likely to retire early when their husband's retirement income is high, and the results are robust across formulations. This conclusion reinforces the regression results for this variable, discussed above.

The other family variables also perform well. AGEDIFF is strongly linked with very early retirement (prior to age 62), though not with the other retirement combinations. The resuits for HPOOR are similar to those discerned in the regression context: wives with husbands in poor health delay retirement. This effect is strongest for the very early $(<62)$ and early $(62 \leq$ 
RETAGE 65 ) retirement choices. Finally, neither HRET nor DEPCH is significantly associated with any of the retirement choices in this setup. This contrasts with the results discussed by Henretta and $0^{\prime}$ Rand $(1980,1983)$ and Clark et al. (1990), probably because those studies do not control on income and leisure opportunities as we have here.

In order to test the underlying validity of the IIA assumption discussed earlier, we undertake three formal tests, each of which uses the PVY-RET formulation in column 1 of Table 622. The first test, described by Hausman and McFadden (1981), compares coefficient estimates derived from using the full data set, with those derived from using data subsets. Estimated $T$ values range between 1.7 and 3.4 , far smaller than the critical values of $T$ required to reject the null hypothesis of IIA. ${ }^{23}$ The IIA hypothesis is also not rejected using Small's (1981) procedure. This approach essentially adds another variable to the model which permits "nearby" alternatives to affect utility of an alternative actually chosen. We cannot reject the null hypothesis, which is that the estimated coefficient on the additional variable equals zero. 24 The final test of the IIA assumption is a simple Chi-square test. This compares predicted probabilities in the simple logit model, with those from the 22These tests cannot be readily applied to the mixed Logit formulations.

23with 2 degrees of freedom, the critical value is 10.6 at $p=0.005$, and 5.9 at $p=0.05$.

${ }^{24}$ The estimated coefficjent value on this new variable is -0.2 , with a $t$ statistic of -0.42 . 
TABIE 6

ESTIMATED UTILITY FUNCTION PARAMETERS FOR HARRIED WOKEN: LOGIT COEEEICIENSS ${ }^{a}$

Dependent Variable $=$ CHOICE.

\begin{tabular}{|c|c|c|c|c|c|}
\hline \multicolumn{2}{|c|}{ EXPLANATOSY VARIAELES } & 11. & {$[2]$} & {$[3]$} & [4] \\
\hline \multicolumn{2}{|c|}{$\begin{array}{l}\text { A. Incone: } \\
\text { LNPVY }\end{array}$} & $\begin{array}{c}0.05 \\
{[0.89]}\end{array}$ & $\begin{array}{c}0.03 \\
{[0.48]}\end{array}$ & $\begin{array}{c}-0.02 \\
{[0.22]}\end{array}$ & $\begin{array}{l}-0.01 \\
{[0.1 \%]}\end{array}$ \\
\hline LNHPYYR & $\begin{array}{l}\text { P1/P4 } \\
\text { P2/P4 } \\
\text { P3/P4 }\end{array}$ & & $\begin{array}{c}-1.88 \\
{[2.51]} \\
-1.38 \\
{[2.47]} \\
-0.66 \\
{[2.60]}\end{array}$ & $\begin{array}{c}-1.93 \\
{[2.06]} \\
-1.20 \\
{[1.72]} \\
-0.59 \\
{[1.84]}\end{array}$ & $\begin{array}{c}-1.74 \\
{[1.76]} \\
-1.05 \\
{[1.42]} \\
-0.43 \\
{[1.25]}\end{array}$ \\
\hline \multicolumn{6}{|c|}{$\begin{array}{l}\text { B. RET: } \\
\text { LNREI } \\
\text { C. Family } \\
\text { Rosponsibilitios }\end{array}$} \\
\hline AGEDIFE & $\begin{array}{l}\mathrm{P} 1 / \mathrm{P}_{4} \\
\mathrm{P} 2 / \mathrm{P}_{4} \\
\mathrm{P} 3 / \mathrm{P}_{4}\end{array}$ & & & $\begin{array}{c}0.50 \\
{[2.97]} \\
0.16 \\
{[1.04]} \\
-0.004 \\
{[0.03]}\end{array}$ & $\begin{array}{c}0.43 \\
{[2.43]} \\
0.10 \\
{[0.62]} \\
-0.07 \\
{[0.39]}\end{array}$ \\
\hline DEPCH & $\begin{array}{l}\mathrm{P} 1 / \mathrm{P4} \\
\mathrm{P} 2 / \mathrm{P} 4 \\
\mathrm{P} 3 / \mathrm{P4}\end{array}$ & & & $\begin{array}{c}-0.96 \\
{[1.14]} \\
-0.21 \\
{[0.27]} \\
0.76 \\
{[0.92]}\end{array}$ & $\begin{array}{c}-0.98 \\
{[1.15]} \\
-0.46 \\
{[0.57]} \\
0.29 \\
{[0.34]}\end{array}$ \\
\hline HHPOOR & $\begin{array}{l}\mathrm{P} 1 / \mathrm{P} 4 \\
\mathrm{P} 2 / \mathrm{P} 4 \\
\mathrm{P} 3 / \mathrm{P} 4\end{array}$ & & & & $\begin{array}{c}-2.95 \\
{[2.22]} \\
-1.98 \\
{[1.96]} \\
e\end{array}$ \\
\hline \multicolumn{2}{|l|}{ KRET } & & & $\begin{array}{l}-0.24 \\
{[0.59]}\end{array}$ & $\begin{array}{l}-0.28 \\
{[0.66]}\end{array}$ \\
\hline \multicolumn{2}{|c|}{ Log libelihood Ratio } & -171 & -167 & -139 & -126 \\
\hline \multicolumn{2}{|c|}{ Sagale Size } & 139 & 139 & $124^{c}$ & $114^{d}$ \\
\hline
\end{tabular}


TABLE 6 (COHTINUED)

ESTIYA'LED UTILTTY FUNCTION PARAMETERS FUR MARRIED WOMEN: LOGIT COERTICIENTS

Notes:

a. Pi $(i=1,2,3)$ indicates the probability the iti choico will be made, so Pl/PA is the ratio of the probahility of choice 1 to 4 . T-statistics are shown in brackets.

b. Income values are in thousands of 1970 doliars.

c. Sample size is reduced to 124 because of missing data. The frequenoy of CHOICE 1 is $39 \%$; of CHOICE 2 is 36\%; of CHOICE 3 is 15\%; and of CHOICE 4 is $10 \%$.

d. Sample size is reduced to 114 because of missing data. The frequency of CHOICE 1 is 30\%; of CHOICE 2 is 36\%;

of CHOICE 3 is 15\%; and of CHOICE 4 is $11 \%$.

e. Convergence not achieved due to lack of varintion for this CHOICE category. 
ordered Logit model, as described in Fields and Mitchell $(1984 b)$. Here too, we cannot reject the null hypothesis that IIA holds. 25 In other words, the IIA assumption in the simple Logit framework appears to be appropriate for examining women's retirement patterns.

\section{IV. conclusions}

This study has two objectives: (1) to examine how economic factors affect wives' retirement patterns, and (2) to establish the relative importance of family considerations in married women's retirement decisions. We formulate a life cycle model and test it using two empirical frameworks.

In both formulations, our results indicate that wives' own economic opportunities tend to be insignificant determinants of their retirement patterns. This conclusion contrasts sharply with evidence for male workers, where economic opportunities tend to play a more powerful role. In contrast, other variables are more important for women. Specifically, married women appear to value nonwork years highly, particularly if their spouse is much older than they. This may imply some complementarity between spouses' nonwork time. Having a husband in poor health appears to increase rather than impede a working woman's continued labor force attachment, but the presence of dependent children has no discernable impact. Higher husiond's income tends to be associated with delayed retirement among

2JThe calculated value of the test statistic is 0.001 , with 3 degrees of freedom, whereas the critical value is 12.8 at
$p=0.005$, and 7.8 at $p=0.05$. 
wives, possible evidence for marital selection in tastes toward work.

Our results have important implications for lawmakers, especially those pertaining to retirement responsiveness to pension and Social Security income. Previous findings indicate that men do not.defer retirement by very much, when faced with cuts in Social security or pension benefits. 26 our data suggest that women will probably defer retirement by less, if at all. Hence, we predict that benefit reductions intended to induce delayed retirement will not substantially alter working couple's retirement patterns. As a result, we expect that retirement income for older families will fall.

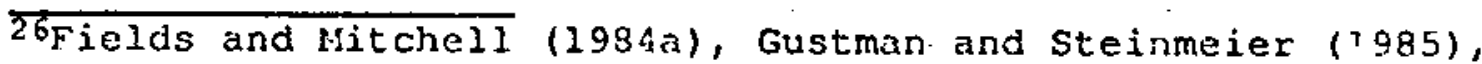
Zabalza and Piachaud (1981). 


\section{References}

Bazzoli, G.J. "The Early Retirement Decision: New Fmpirical Evidence on the Influence of Health" Jourozl of HumanReseurcas 20 (Spring 1985).

Bowen, W. G., and T. A. Finegan. The Economics of Labor Eerce Participation. Princeton, NJ: Princeton University Press, 1969.

Burbidge, J.B., and A.L. Robb. "Pensions and Retirement Behavior." Canadian. Jounal of Economics 13 (August 1980): $421-437$.

Clark, R. L., and T. Johnson. "Retirement in the Dual Career Family." Final Report for Social Security

Administration Grant No. 10-P-90543-4-02, 1980.

Clark, R.L., T. Johnson, and A.A. McDermed. "Aljocation of Time and Resources by Married Couples Approaching Retixement." Social Security Bulletin 43 (April 1980): 3-15.

Fields, G.S., and O.S. Mitchell. "The Effects of Social Security Reforms on Retirement Ages and Retirement Incomes". Journal of Public Economics 25 (November 1984): $143-159$.

Fields, G.S., and O.S. Mitchell. Retirement, Pensions, and Social Security. Cambridge, MA.: The MIT Press, 1984. (1984b).

Gustman, A. and T. Steinmeier. "A Structural Retirement Model". Econemetrica 54 (May 1986): 555-584.

Hausman, J., and D. McFadden. "Specification Tests for the Multinomial Logit Model." Working paper 292.

Massachusetts Institute of Technology, Department of Economics, October 1981.

Hanoch, G., and M. Honig. "Retirement, Wages, and Labor Supply of the Elderly." Jounal of Labor Economics 1 (April 1983): 131-151.

Henretta, J.C., and A. M. O'kand. "Joint Retirement in the Dual Worker Family." Social Eorces 62 (December 1.983): 504-520.

Henretta, J. C., ard A. M. D'Rand. "Labor Force Participation of Older Married Women." Social Security Bulletin 43 (August 1980): 10-16.

Honig, M. "Partial Retirement Among Women." Jourual of Humad Bescurces 20 (Fa.l1 1985): 613-621. 
Honig, M. and G. Hanoch. "Partial Retirement As a Separate Mode of Retirement Behavior." Journal of Human Besources 20 (Winter 1985): 21-46.

Killingsworth, M. R. Labor Supply. New York: Cambridge University Press, 1983.

Kotlikoff, L. and D. E. Smith. Pensions.and the_American Economy. Chicago: University of Chicago Press, 1983:

Lazear, E. P. and S. Rosen. "Pension inequality." Working Paper No. 1477. National Bureau of Economic Research, October 1984.

MacDonald, G. and G. Carliner. "How Does the Structure of Pension Benefits Influence the Optimal Retirement Age?" Unpublished working paper, University of Western Ontario, November 1982 .

McFadden, D. "Econometric Models of Probabalistic Choice". In Structural Analysis of Discrete Data with Econometric Applications. Ed. by D. Manski and D. McFadden. Cambridge, MA: MIT Press, 1981.

Mitchell, O. S., and G. S. Fields. "The Effects of Pensions and Earnings on Retirement: A Review Essay." In Research in Labor Economics vol. 5. Edited by $R$. Ehrenberg. Greenwich, Conn.: JAI Press, 1982.

Schwab, K. and I.M. Irelan. "The Social Security Administration's Retirement History Study." In Aging, and Retirement: Prospects, Planning and Policy. Edited by N.G. McCluskey and E.F. Bergatta. Beverly Hills: Sage Publications, Inc., 1981.

Small, K. "Ordered Logit: A Discrete Choice Model with Proximate Covariance among Alternatives." Econometric Research Program Memorandum 292. Princeton University, December, 1981.

U.S. Department of Health, Education, and Welfare. National. Center for Health Statistics. U.S. Decenaial hife Tables for 1969-1971: U.S. Iife Tables 1969-71. Washington, D.C.: May, 1975.

U.S. Department of Labor. Bureau of Labor Statistics. Handbook of Iabor Statistics. Bulletin 2217. washington, D.C.: Government Printing office, June, 1985 .

Zabalza, A. and D. Piachaud. "Social Security and the Elderly: A Simulation of Policy Changes". Jowrnal of Public Economics 16 (October 1981): 145-170. 